\title{
PENGARUH PENAMBAHAN PUPUK ORGANIK GUANO DENGAN KONSENTRASI YANG BERBEDA TERHADAP LAJU PERTUMBUHAN Spirulina sp.
}

\section{THE EFFECT OF GUANO ORGANIC FERTILIZER UTILIZATION WITH DIFFERENT CONCENTRATIONS ON THE GROWTH RATE OF Spirulina sp.}

\author{
Viqran ${ }^{1 *}$, Zaenal Abidin ${ }^{1)}$, Alis Mukhlis ${ }^{1)}$, \\ ${ }^{1)}$ Fakultas Pertanian, Program Studi Budidaya Perairan, Universitas Mataram \\ Jl. Pendididkan No. 37 Mataram, NTB
}

\begin{abstract}
Abstrak
Penelitian ini bertujuan untuk mengetahui pengaruh konsentrasi pupuk organik guano kelelawar yang tepat terhadap pertumbuhan mikroalga Spirulina sp. Metode digunakan dalam penelitian ini yaitu metode eksperimen dengan Rancangan Acak Lengkap (RAL). Penelitian ini menggunakan 6 perlakuan dengan konsentrasi pemberian pupuk yang berbeda yaitu pupuk komersil sebagai kontrol positif, $0 \mathrm{~g} / \mathrm{L}$ sebagai kontrol negatif, guano $0,040 \mathrm{~g} / \mathrm{L}$, guano $0,060 \mathrm{~g} / \mathrm{L}$, guano $0,080 \mathrm{~g} / \mathrm{L}$ dan guano $0,100 \mathrm{~g} / \mathrm{L}$ yang masing-masing diulang sebanyak 3 kali. Kepadatan awal penebaran 1.500 unit/mL yang dipelihara selama 96 jam. Pengamatan kepadatan dilakukan setiap 12 jam. Parameter yang diamati meliputi kepadatan puncak, pertumbuhan mutlak, laju pertumbuhan spesifik, pertumbuhan biomassa, dan waktu penggandaan diri. Hasil penelitian menujukkan bahwa konsentrasi $0,100 \mathrm{~g} / \mathrm{L}$ menghasilkan pertumbuhan populasi Spirulina sp. tertinggi dengan nilai rata-rata $6.572 \mathrm{unit} / \mathrm{mL}$ dengan pertumbuhan mutlak tertinggi dengan nilai rata-rata $5.072 \mathrm{unit} / \mathrm{mL}$ dan waktu penggandaan diri tercepat yaitu 36,76 jam. Namun dalam percobaan ini tidak menunjukkan pengaruh yang berbeda nyata terhadap hasil pertumbuhan biomassa.
\end{abstract}

Kata kunci : pupuk guano, pertumbuhan, Spirulina sp.

\begin{abstract}
Aim of study is to determine effect of the different concentration of bat guano organic fertilizer on the growth of Spirulina sp. Microalgae. Completely randomized design (CRD) was applied in this experimen. This study used 6 treatments with different concentrations of fertilizer, namely commercial fertilizer as a positive control, $0 \mathrm{~g} / \mathrm{L}$ as a negative control, guano $0,040 \mathrm{~g} / \mathrm{L}$, guano $0,060 \mathrm{~g} / \mathrm{L}$, guano $0,080 \mathrm{~g} / \mathrm{L}$ and guano $0,100 \mathrm{~g} / \mathrm{L}$ which were repeated 3 times. Initial density of 1,500 units $/ \mathrm{mL}$ stocking was maintained for 96 hours. Observation of density was carried out every 12 hours. Measured parameters were peak density, absolute growth, specific growth rate, biomass growth, and doubling time. The results showed that the concentration of $0,100 \mathrm{~g} / \mathrm{L}$ was the highest in growth of Spirulina sp. population with an average of 6,572 units $/ \mathrm{mL}$ and highest in absolute growth with an average of 5,072 units $/ \mathrm{mL}$ and the fastest in doubling time of 36,76 hours, however there were no significant effect on biomass productions compare to other concentrations.
\end{abstract}

Keywords : guano fertilizer, growth, Spirulina sp

\section{Pendahuluan}

Salah satu jenis mikroalga yang telah banyak dimanfaatkan untuk kepentingan budidaya adalah Spirulina sp. Spirulina dimanfaatkan sebagai pakan alami pada organisme budidaya laut. Spirulina merupakan alga hijau berfilamen yang sudah banyak digunakan sebagai sumber pakan alami untuk pembenihan udang, ikan, dan krustase karena *korespondensi : viqran22@gmail.com memiliki nilai nutrisi yang tinggi. Kandungan protein Spirulina sp. adalah 60-70\%, sekitar 85$95 \%$ dari protein tersebut dapat dicerna dengan baik, sedangkan lemaknya cukup rendah yaitu 1,5-12\% (Ciferri, 1983).

Pemenuhan kebutuhan nutrien untuk Spirulina sp. sangat bergantung pada ketersediaannya dalam medium kultur. Jenis pupuk yang banyak dipilih masyarakat dalam kultur Spirulina sp. adalah jenis PA (Pro 
Analisis) yang sudah distandarkan seperti pupuk Walne, Guillard, dan lainnya. Namun jenis-jenis pupuk ini sulit diperoleh, harga relatif mahal dan membutuhkan komposisi larutan nutrien yang cukup banyak dalam pembuatannya. Harga pupuk Walne di pasaran adalah Rp 500-1000/mL, sedangkan pupuk Guillard adalah Rp400.000/L. Mahalnya harga pupuk jenis PA menjadi dasar pencarian pupuk alternatif pada kultur Spirulina sp. yang mampu menghasilkan kepadatan sel yang tinggi, dengan harga yang ekonomis dan murah diperoleh oleh masyarakat. Memenuhi kebutuhan unsur hara dalam media kultur spirulina, masyarakat biasanya menggunakan pupuk SP-36, NPK, dan Urea yang banyak dijual di pasaran. Namun demikian, jenis-jenis pupuk ini hanya dapat memenuhi kebutuhan unsur hara makro saja sehingga dibutuhkan tambahan unsur hara mikro sebagai pelengkap nutrisi untuk pertumbuhan Spirulina. Salah satu alternatif sumber unsur hara mikro adalah limbah kotoran kelelawar (Guano) yang diketahui banyak mengandung Potasium, Calcium, Magnesium, Zinc, Copper, Manganese, dan Sodium (Anonim, 2016).

\section{Metode Penelitian}

Penelitian ini dilaksanakan pada bulan Februari 2018 di Laboratorium Mandiri yang terletak di Perumnas, Batanghari 2 no 31, Tanjung Karang Permai, Mataram. Sempel diamati di Laboratorium Program Studi Budidaya Perairan Universitas Mataram.

\section{Metode dan rancangan percobaan}

Rancangan penelitian yang digunakan yaituRancangan Acak Lengkap (RAL) dengan 6 perlakuan dengan 3 kali ulangan yaitu Urea $0.10 \mathrm{~g} / \mathrm{l}, \mathrm{SP}-360.061 \mathrm{~g} / \mathrm{l}$, EDTA $0.005 \mathrm{~g} / \mathrm{l}$ dan $\mathrm{FeCl} 30.002 \mathrm{~g} / \mathrm{L}$ (kontrol positif), Guano $0 \mathrm{~g} / \mathrm{L}$ (kontrol negatif), Guano 0,040 g/L, Guano 0,060 g/L, Guano 0,080 g/L, dan Guano 0,100 $\mathrm{g} / \mathrm{L}$.

\section{Persiapan alat dan wadah}

Bak pemeliharaan, selang aerasi, batu aerasi, gelas ukur, wadah kultur dan botol sampel terlebih dahulu dicuci menggunakan sabun cuci, kemudian dibilas dengan air tawar hingga bersih dan kemudian dikeringkan. Wadah kultur di pasang aerasi sebanyak 1 buah, kemudian ditutup dengan rapat dan di tempatkan dalam ruang budidaya dengan pemberian sumber cahaya dari lampu TL 40 watt dengan intensitas cahaya 2000-3000 lumens.

\section{Persiapan air media}

Air yang digunakan sebagai media kultur Spirulina adalah air tawar yang diperoleh dari sumur. Sebelum digunakan, air media disaring terlebih dahulu agar tidak terkontaminasi oleh saringan yang digunakan. Setelah disaring, air dipanaskan hingga mendidih selama 10 menit agar semua patogen yang hidup di dalam air dapat mati atau inaktif. Setelah dimasak langsung dituang dalam bak penelitian yang telah dibersihkan masing-masing sebanyak 4 liter. Air tersebut diberi aerasi selama 24 jam serta ditutup rapat agar kotoran dari luar tidak masuk kedalam wadah.

\section{Persiapan pupuk}

Pupuk guano diproleh dari jasa penyedia pupuk yang telah banyak dijual secara online. Pupuk guano yang dijual secara online sudah dalam keadaan kering dan berbentuk tepung halus, sehingga tidak perlu dilakukannya pengeringan dan penggilingan pupuk lagi. Pupuk guano yang halus dilarutkan dalam aquades dengan perbandingan $1 \mathrm{~kg}$ pupuk guano : 4 liter aquades serta ditambahkan bakteri pengurai (EM4) sebanyak $1 \mathrm{ml} / \mathrm{l}$ dan ditutup rapat, selanjutnya disimpan pada tempat yang teduh selama seminggu. Setelah satu minggu, larutan tersebut disaring menggunakan saringan kantong untuk memisahkan ampas pupuk dengan larutan. Ampas dikeringkan ke dalam oven dengan suhu 120 0C selama 1 jam dan ditimbang untuk mengetahui selisih pupuk yang terlarut dalam aquades. Konsentrasi pemberian pupuk guano disesuaikan dengan perlakuan yang telah ditentukan sebelumnya. Untuk menentukan berapa banyak larutan pupuk yang diberikan pada perlakuan, terlebih dahulu harus mengetahui berapa gram pupuk yang terlarut dalam aquades. Untuk mengetahui konsentrasi pupuk dapat menggunakan rumus : $\mathrm{K}=\frac{a-b}{c} . \mathrm{K}=$ Konsentrasi pupuk $(\mathrm{g} / \mathrm{L}) ; \mathrm{a}=$ Pupuk yang difermentasi (g); $\mathrm{b}=$ Ampas hasil fermentasi $(\mathrm{g}) ; \mathrm{c}=$ Jumlah aquades yang digunakan (L). Persedian pupuk anorganik dilakukan dengan cara melarutkan kedalam botol volume $500 \mathrm{ml}$ air. Untuk medapatkan konsentrasi Urea $0.10 \mathrm{~g} / \mathrm{l}$, SP-36 $0.061 \mathrm{~g} / \mathrm{l}$, EDTA 0.005 g/l dan $\mathrm{FeCl}_{3} 0.002 \mathrm{~g} / \mathrm{l}$, perhitungan setiap pupuk dapat menggunakan rumus : $\mathrm{P}=\mathrm{A} x \mathrm{~V} . \mathrm{P}=$ Pupuk yang dibutuhkan 
(mg); A = Jumlah pupuk anorganik yang telah ditentukan (mg); $\mathrm{V}=$ Volume air yang diinginkan dalam pembuatan pupuk $(\mathrm{mL})$.

\section{Persiapan bibit Spirulina sp.}

Bibit Spirulina diperoleh dari jasa penyedia bibit starter yang telah banyak dijual secara online dan diperbanyak di Laboratorium Mandiri yang terletak di Perumnas, Batanghari 2 no 31, Tanjung Karang Permai, Mataram. Kultur Spirulina sp. dimulai dengan menggunakan bibit starter $500 \mathrm{ml}$ dikultur pada volume 10 liter, pada hari ke 4 dilakukan penambahan pupuk dengan konsentrasi yang sama, kemudian dipanen pada hari ke 8 dan dikultur kembali pada volume 50 liter, dan dilakukan pemupukan kembali pada hari ke 4 dan dipelihara hingga hari ke 8 atau mencapai kepadatan lebih dari 2.500 unit/mL. Kultur ini menggunakan pupuk Urea $0.10 \mathrm{~g} / \mathrm{l}$, SP-36 $0.061 \mathrm{~g} / \mathrm{l}$, EDTA $0.005 \mathrm{~g} / \mathrm{l}$ dan $\mathrm{FeCl} 30.002 \mathrm{~g} / \mathrm{l}$. Persiapan bibit mengikuti penelitian dari Hermansyah (2015). Spirulina dihitung menggunakan bantuan Sedgewick rafter dengan rumus : $\mathrm{K}=\mathrm{N}$ x 250 . $\mathrm{K}=$ Kepadatan fitopalankton (unit $/ \mathrm{mL}$ ); $\mathrm{N}=$ Rata-rata jumlah unit dalam satu lapang pandang yang terdiri dari 4 kotak pengamatan (unit); $250=$ Faktor pengali untuk pengamatan dalam 4 kotak dari 1000 kotak yang ada di sedgewick rafter.

\section{Penebaran bibit Spirulina sp.}

Kepadatan Spirulina sp. dalam wadah penampungan dihitung untuk menentukan volume spirulina yang harus diambil agar mencapai kepadatan 1.500 unit $/ \mathrm{mL}$ pada masing-masing unit percobaan. Volume bibit Spirulina yang akan diambil untuk ditebar ditentukan dengan menggunakan rumus : $V_{1}=\frac{N_{2} x V_{2}}{N_{1}} \cdot \mathrm{V}_{1}=$ Volume bibit untuk penebaran awal $(\mathrm{mL}) ; \quad \mathrm{N}_{1}=$ Kepadatan bibit/stock Spirulina sp. (unit $/ \mathrm{mL}$ ); $\mathrm{V}_{2}=$ Volume media kultur yang dikehendaki (mL); $\mathrm{N}_{2}=$ Kepadatan bibit Spirulina sp. yang dikehendaki (unit/mL).

\section{Pemberian pupuk Guano}

Konsentrasi pemberian pupuk guano untuk setiap perlakuan diketahui dengan menggunakan rumus pengenceran sesuai dengan konsentrasi pupuk guano yang terlarut dalam aquades. Pemberian pupuk dikakukan sebelum bibit Spirulina dimasukkan kedalam wadah penelitian.

\section{Pemeliharaan dan pengumpulan data}

Pengamatan kepadatan Spirulina sp. diamati menggunakan Sedgewick rafter dan mikroskop dengan pembesaran 100 kali. Pengamatan dilakukan dengan cara mengambil sampel budidaya yang akan dihitung kepadatannya menggunakan pipet tetes sebanyak $1 \mathrm{~mL}$ dan diteteskan pada Sedgewick rafter. Pengamatan kepadatan Spirulina sp. mulai dilakukan sejak jam ke 0 (awal penebaran) dan setiap 12 jam hingga terjadi penurunan kepadatan. Perhitungan Spirulina sp. pada Sedgewick rafter dilakukan pada 4 kotak bidang pandang sebanyak 3 kali ulangan. Parameter pendukung yang diukur adalah $\mathrm{pH}$ dan suhu.

\section{Pengukuran biomassa Spirulina sp.}

Perhitungan biomassa Spirulina dilakukan setelah sampel yang akan dihitung melalui beberapa proses terlebih dahulu, yakni kertas filter ditimbang terlebih dahulu untuk mengetahui berat kertas filter, kemudian sampel diambil sebanyak $100 \mathrm{ml}$ dan disaring menggunakan kertas filter, kertas filter dikeringkan selama 2 jam dengan suhu $110{ }^{\circ} \mathrm{C}$ dalam oven. Kemudian kertas ditimbang untuk mengetahui berat sampel. Pengukuran biomassa dilakukan pada jam ke 60, 72, dan 84 (tergantung waktu pertumbuhan puncak).

\section{Variabel penelitian dan cara perhitungannya}

Variabel penelitian ini terdiri atas variabel utama dan variabel pendukung. Variabel utama meliputi pertumbuhan kepadatan, kepadatan puncak, biomasa, waktu penggandaan, dan berat kering. Variabel pendukung meliputi kualitas air suhu dan $\mathrm{pH}$.

\section{Pertambahan kepadatan}

Pertambahan kepadatan dan biomassa spirulina dihitung menggunakan rumus; $G R=$ $W t-W 0$. GR $=$ Pertambahan kepadatan (unit $/ \mathrm{mL}$ ); Wt $=$ Kepadatan puncak/biomassa Spirulina sp. (unit $/ \mathrm{mL}$ ); Wo = Kepadatan tebar/biomassa Spirulina sp. pada jam ke 0 (unit $/ \mathrm{mL}$ ). 


\section{Pertambahan berat}

Perhitungan berat Spirulina dilakukan melalui beberapa proses terlebih dahulu, yaitu kertas filter ditimbang untuk mengetahui berat kertas filter, kemudian sampel diambil sebanyak $100 \mathrm{ml}$ dan disaring menggunakan kertas filter, kertas filter dikeringkan selama 2 jam dengan suhu $110{ }^{\circ} \mathrm{C}$ dalam oven. Kemudian kertas ditimbang untuk mengetahui berat sampel. Pengukuran berat dilakukan pada jam ke 0 (sebelum percobaan) dan pada pertumbuhan puncak. Sehingga dapat diketahui pertambahan berat Spirulina selama penelitian.

\section{Kepadatan puncak}

Kepadatan puncak Spirulina sp. dihitung dengan melihat kenaikan jumlah unit $/ \mathrm{ml}$ tertinggi pada saat percobaan.

\section{Laju pertumbuhan Spesifik/ Spesific Growth Rate (SGR)}

Laju pertumbuhan spesifik Spirulina sp. dihitung dengan menggunakan rumus berikut: SGR $=\left(\left(C_{t} / C_{0}\right)^{1 / t}-1\right) \times 100 \%$ (Mukhlis, dkk., 2017). SGR = Laju pertumbuhan spesifik (\% I jam) $\mathrm{C}_{0}=$ Kepadatan Spirulina sp. awal (unit $/ \mathrm{mL}$ ); $\mathrm{C}_{\mathrm{t}}=$ Kepadatan Spirulina sp. akhir (unit $/ \mathrm{mL}$ ); $\mathrm{t}=$ Selang waktu dari $\mathrm{W}_{0}$ ke $\mathrm{W}_{\mathrm{t}}$ (jam).

\section{Waktu penggandaan}

Waktu penggandaan Spirulina sp. dihitung dengan menggunakan rumus : DT $=\log (2) \times$ $\Delta t /\left(\log C_{t}-\log C_{0}\right)$ (Mukhlis, dkk., 2017). DT = Double time (jam); $\Delta \mathrm{t}=$ Lama waktu dalam satu priode pengamatan (jam); $C_{0}=$ Kepadatan populasi awal periode (unit $/ \mathrm{mL}$ ); $C_{t}=$ Kepadatan populasi akhir periode (unit/mL).

\section{Kualitas air}

Parameter kualitas air yang diukur yaitu suhu dan $\mathrm{pH}$.

\section{Analisis data}

Data variabel penelitian yang diperoleh, dianalisis menggunakan analisis sidik ragam (ANOVA) pada taraf kesalahan 5\% dengan menggunakan program costat. Apabila hasil analisis menunjukkan berbeda nyata atau memberikan pengaruh (significant) maka analisis dilanjutkan dengan uji Beda Nyata Terkecil (BNT).

\section{Hasil}

Hasil pengamatan rata-rata kepadatan Spirulina sp. selama 96 jam yang diberi pupuk guano dengan konsentrasi yang berbeda ditampilkan pada Gambar 1. Kepadatan populasi Spirulina sp. tertinggi yang dicapai pada jam ke-72 ditunjukkan oleh perlakuan Kontrol Positif, Kontrol Negatif, Guano 0,040 $\mathrm{g} / \mathrm{L}$, dan Guano 0,080 g/L, sedangkan pada perlakuan Guano $0,060 \mathrm{~g} / \mathrm{L}$ dan perlakuan Guano $0,100 \mathrm{~g} / \mathrm{L}$ dicapai pada jam ke-84. Hasil penelitian menunjukkan bahwa konsentrasi pupuk Guano 0,100 g/L, menghasilkan kepadatan populasi tertinggi yaitu 6.572 unit $/ \mathrm{mL}$.

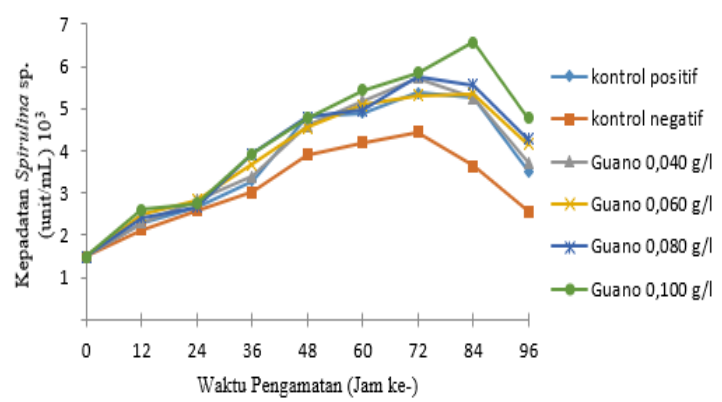

Gambar 1. Grafik kurva rata-rata kepadatan Spirulina sp. setiap 12 jam dengan konsentrasi pupuk guano yang berbeda

Tabel 1. Menunjukkan bahwa laju pertumbuhan mutlak Spirulina sp. tertinggi terdapat pada perlakuan Guano 0,100 g/L dengan nilai rata-rata sebesar $5.072 \pm 147,45$ unit/mL. Pertumbuhan mutlak tertinggi selanjutnya yaitu perlakuan Guano $0,080 \mathrm{~g} / \mathrm{L}$ dengan nilai rata-rata sebesar $4.260 \pm 538,49$ unit $/ \mathrm{mL}$, perlakuan Guano 0,040 g/L dengan nilai rata-rata sebesar $4.299 \pm 222,00 \mathrm{unit} / \mathrm{mL}$, perlakuan Kontrol Negatif dengan nilai ratarata sebesar $4.228 \pm 527,09$ unit $/ \mathrm{mL}$, dan perlakuan Guano 0,060 g/L dengan nilai ratarata sebesar $3.884 \pm 98,88 \mathrm{unit} / \mathrm{mL}$. Pada penelitian ini nilai laju pertumbuhan mutlak terendah terdapat pada perlakuan Kontrol Negatif dengan nilai rata-rata sebesar $3.114 \pm$ 203,21 unit/mL. Laju pertumbuhan spesifik tertinggi terdapat pada perlakuan Guano 0,040 $\mathrm{g} / \mathrm{L}$ yaitu $1,88 \pm 0,05 \%$ per jam dan perlakuan Guano $0,080 \mathrm{~g} / \mathrm{L}$ yaitu $1,88 \pm 0,013 \%$ per jam. Laju pertumbuhan spesifik tertinggi selanjutnya yaitu pada perlakuan Guano 0,100 $\mathrm{g} / \mathrm{L}$ dengan rerata pertumbuhan sebesar 1,77 \pm $0,03 \%$ per jam, perlakuan Kontrol Positif 
dengan rerata pertumbuhan sebesar 1,70 $\pm 0,23$ $\%$ per jam, dan perlakuan Guano 0,060 g/L dengan rerata pertumbuhan sebesar 1,62 $\pm 0,13$ $\%$ per jam. Penelitian ini, nilai laju pertumbuhan spesifik terendah terdapat pada perlakuan Kontrol Negatif dengan rerata pertumbuhan sebesar $1,57 \pm 0,06 \%$ per jam. Perhitungan pertumbuhan biomassa (berat kering) Spirulina sp. data dikalkulasi dari data biomassa awal dengan data biomassa akhir (kepadatan puncak). Hasil perhitungan menujukkan hasil yang tidak berbeda nyata dari semua perlakuan. Hasil waktu penggandaan perhitungan menunjukkan bahwa pada perlakuan Guano 0,100 g/L menghasilkan waktu penggandaan tercepat yaitu 36,76 $\pm 1,90$ jam. Urutan waktu penggandaan tercepat selanjutnya yaitu pada perlakuan Guano 0,040 $\mathrm{g} / \mathrm{L}$ yaitu 37,28 $\pm 1,07$ jam, perlakuan Guano $0,080 \mathrm{~g} / \mathrm{L}$ yaitu $37,29 \pm 2,53 \mathrm{jam}$, perlakuan Kontrol Positif yaitu 39,42 $\pm 3,77$ jam, dan perlakuan Guano 0,060 g/L yaitu 39,42 $\pm 0,64$ jam. Dalam penelitian ini waktu penggandaan terlama terdapat pada perlakuan Kontrol Negatif yaitu 46,57 \pm 5,26 jam.

\section{Pembahasan}

Gambar 1. menunjukkan perkembangan kepadatan Spirulina sp. selama 96 jam masa kultur. Pertumbuhan Spirulina sp. pada penelitian ini meliputi beberapa fase yaitu fase lag, fase eksponensial, fase stationer, dan fase kematian. Fase lag ditandai dengan adanya pertumbuhan populasi yang lambat karena alokasi energi dipusatkan untuk penyesuaian diri terhadap media kultur yang baru. Fase kelambanan (lag fase), yaitu tahap dimana selsel Spirulina sp. menyesuaikan diri dengan lingkungan barunya (Hariyati, 2008). Hal ini dijelaskan juga oleh Muhammad (2007), bahwa pada fase lag atau adaptasi populasi yang baru ditransfer mengalami penurunan tingkat metabolisme akibat perbedaan fase penumbuhan inokulum dan terjadi proses adaptasi terhadap media kultur. Pada pernyatan tersebut dapat diketahui pertumbuhan kepadatan pada fase lag dapat mengalami penurunan atau sedikit pertambahan kepadatan

Tabel 1. Hasil analisis sidik ragam (ANOVA) rata-rata pertumbuhan mutlak, biomassa, kepadatan puncak, laju pertumbuhan spesifik dan waktu penggandaan Spirulina sp.

\begin{tabular}{lcccccc}
\hline & \multicolumn{5}{c}{ Perlakuan } \\
\cline { 2 - 6 } Parameter & Kontrol & Kontrol & Guano & Guano & Guano & Guano \\
& Positif & Negatif & $0,040 \mathrm{~g} / \mathrm{L}$ & $0,060 \mathrm{~g} / \mathrm{L}$ & $0,080 \mathrm{~g} / \mathrm{L}$ & $0,100 \mathrm{~g} / \mathrm{L}$ \\
\hline Pertumbuhan & 4.228 & 3.114 & 4.229 & 3.884 & 4.260 & 5.072 \\
mutlak (unit/mL) & $\pm 527,09^{\mathrm{b}}$ & $\pm 203,21^{\mathrm{a}}$ & $\pm 222,0^{\mathrm{b}}$ & $\pm 98,88^{\mathrm{b}}$ & $\pm 538,46^{\mathrm{b}}$ & $\pm 147,45^{\mathrm{c}}$ \\
Biomassa & 0,07753 & 0,06391 & 0,06299 & 0,06266 & 0,07290 & 0,06679 \\
(mg/unit) & $\pm 0,017903^{\mathrm{a}}$ & $\pm 0,031933^{\mathrm{a}}$ & $\pm 0,029230^{\mathrm{a}}$ & $\pm 0,030416^{\mathrm{a}}$ & $\pm 0,022778^{\mathrm{a}}$ & $\pm 0,016102^{\mathrm{a}}$ \\
Kepadatan & 5.728 & 4.614 & 5.729 & 5.384 & 5.760 & 6.572 \\
Puncak (unit/mL) & $\pm 527,09^{\mathrm{b}}$ & $\pm 203,21^{\mathrm{a}}$ & $\pm 222,00^{\mathrm{b}}$ & $\pm 98,88^{\mathrm{b}}$ & $\pm 538,49^{\mathrm{b}}$ & $\pm 147,45^{\mathrm{c}}$ \\
Laju & 1,70 & 1,57 & 1,88 & 1,62 & 1,88 & 1,77 \\
Pertumbuhan & $\pm 0,23^{\mathrm{ab}}$ & $\pm 0,06^{\mathrm{a}}$ & $\pm 0,05^{\mathrm{b}}$ & $\pm 0,13^{\mathrm{a}}$ & $\pm 0,013^{\mathrm{b}}$ & $\pm 0,03^{\mathrm{ab}}$ \\
Spesifik (\%/jam) & & & & & \\
Waktu & 39,42 & 46,57 & 37,28 & 39,42 & $37,29 \pm 2,53^{\mathrm{b}}$ & 36,76 \\
Pengandaan (jam) & $\pm 3,77^{\mathrm{b}}$ & $\pm 5,26^{\mathrm{a}}$ & $\pm 1,07^{\mathrm{b}}$ & $\pm 0,64^{\mathrm{b}}$ & $\pm 0^{\mathrm{b}}$ \\
\hline
\end{tabular}

\section{Kualitas air}

Hasil analisis kualitas air Spirulina sp. untuk suhu dan $\mathrm{pH}$ pada setiap perlakuan selama 96 jam masa kultur mengalami peningkatan yaitu suhu berkisar antara $28-30{ }^{\circ} \mathrm{C}$ dan $\mathrm{pH}$ berkisar antara 8,3-8,9. Kisaran kualitas air kultur Spirulina sp. selama masa pemeliharaan memiliki nilai yang optimum untuk pertumbuhan Spirulina sp karena alokasi energi dipusatkan untuk penyesuaian terhadap media kultur yang baru. Namun pada penelitian ini, fase lag berlangsung selama 12 jam. Pada pengamatan jam ke-12 telah mengalami kenaikan kepadatan yaitu 1.791 unit/mL pada perlakuan Guano 0,040 g/L, dan kepadatan 2.737 unit $/ \mathrm{mL}$ pada perlakuan Guano 0,100 g/L dengan kepadatan tebar awal yaitu 1.500 unit $/ \mathrm{mL}$. Pada penelitian Hariyati (2008), fase lag terjadi selama satu hari, kepadatan populasi yang digunakan pada awal kultur Spirulina sp. sebanyak 1.000 
unit $/ \mathrm{mL}$, pada Medium 1 pertambahan kepadatan mencapai 1.538 unit $/ \mathrm{mL}$, dan Medium 2 mencapai 1.493 unit $/ \mathrm{mL}$.

Setelah fase lag, selanjutnya terjadi fase eksponensial (logaritmik) ditandai dengan meningkatnya kepadatan populasi secara signifikan dalam waktu tertentu. Dalam penelitian ini, fase eksponensial terjadi pada jam ke-24 atau memasuki hari ke-2 dengan rata-rata kepadatan yaitu $2.577-2.839 \mathrm{unit} / \mathrm{mL}$, dan berlangsung hingga jam ke-72 atau pada hari ke -3 dengan rata-rata kepadatan 4.437 $5.854 \mathrm{unit} / \mathrm{mL}$. Pada penelitian Hariyati (2008), fase eksponensial terjadi pada hari ke-2 dengan kepadatan rata-rata 2.527 unit/mL, dan berlangsung hingga hari ke-5 dengan kepadatan rata-rata sebesar 10.510 unit $/ \mathrm{mL}$. Menurut Astiani dkk. (2016), pada fase ini terjadi proses pembelahan sel yang menyebabkan meningkatnya pertumbuhan Spirullina sp. Fase eksponensial terjadi dari hari ke-2 sampai hari ke-3. Suantika dan Hendrawandi (2009), menjelaskan bahwa fase ini terjadi ketika nutrisi, $\mathrm{pH}$, dan intensitas cahaya pada medium masih dapat memenuhi kebutuhan fisiologis Spirulina sp. sehingga dalam fase ini sel masih memiliki kemampuan bereproduksi sehingga populasi masih bertambah.

Setelah fase eksponensial, pertumbuhan mulai mengalami perlambatan atau penurunan (fase stasioner). Menurut Fadilla (2010), bahwa pada fase ini laju reproduksi sama dengan laju kematian, dengan demikian penambahan dan pengurangan jumlah fitoplankton relatif sama atau seimbang sehingga kepadatan fitoplankton tetap. Dalam penelitian ini, dapat kita lihat pada Grafik kurva rata-rata kepadatan Spirulina sp. (Gambar 1.), diduga fase stasioner terjadi setelah jam ke-72 atau sebelum jam ke-84. Pada penelitian Agustini (2010), fase logaritmik berlangsung pada hari ke 5-12 dan mulai memasuki fase stasioner awal pada hari ke-13, dan Spirulina platensis dipanen pada fase stasioner awal, karena pada fase ini merupakan fase pertumbuhan optimum pigmen fikobliprotein pada mikroalga Spirulina platensis. Hal ini dijelakan juga oleh Hidayah (2005), bahwa pemanenan mikroalga yang tepat berdasarkan pola pertumbuhan harus dilakukan pada saat mikroalga mencapai puncak populasi, pemanenan terlambat maka sudah banyak terjadi kematian hingga kualitasnya turun.

Fase kematian terjadi ketika menurunnya kepadatan secara signifikan, dapat dilihat pada
Gambar 1. yaitu terjadi pada jam ke 96 dimana semua perlakuan telah mengalami penurunan kepadatan. Penurunan kepadatan yang paling tajam yaitu pada perlakuan Kontrol Negatif yaitu mencapai 1.636 unit/mL, sedangkan penurunan paling sedikit terjadi pada perlakuan Guano 0,060 g/L, Guano 0,080 g/L, dan Guano $0,100 \mathrm{~g} / \mathrm{L}$ yaitu berkisar $1.084-1.166 \mathrm{unit} / \mathrm{mL}$ dalam waktu 24 jam. Menurut Fadilla (2010), menyatakan bahwa pada fase ini laju kematian lebih cepat daripada laju reproduksi, jumlah sel menurun secara geometrik, penurunan kepadatan mikroalga ditandai dengan perubahan kondisi optimum yang dipengaruhi oleh suhu, cahaya, $\mathrm{pH}$ air, jumlah hara yang ada, dan beberapa kondisi lingkungan yang ada.

Penambahan guano dengan konsentrasi berbeda memberikan pengaruh terhadap pertambahan kepadatan. Adanya perbedaan dalam pertambahan kepadatan selama kultur karena adanya perbedaan dalam jumlah nutrien yang tersedia. Pada penelitian ini, nilai pertumbuhan mutlak tertinggi terdapat pada perlakuan Guano 0,100 g/L. Hal ini diduga karena semakin tinggi penambahan pupuk guano maka nutrien yang terdapat dalam media kultur juga akan semakin tinggi. Hal ini dijelaskan juga oleh Santosa (2010), bahwa nutrien merupakan salah satu faktor yang sangat berpengaruh pada pertumbuhan dan komposisi biokimia alga, kondisi nutrien yang optimum sangat penting untuk mendapatkan nilai produktivitas kultur alga yang baik, konsentrasi nutrien yang rendah dapat menyebabkan penurunan laju pertumbuhan karena sel-sel alga kekurangan unsur makanan.

Laju pertumbuhan spesifik menggambarkan kecepatan pertambahan sel alga persatuan waktu yang dapat dipakai tolak ukur untuk mengetahui daya dukung media terhadap pertumbuhan alga. Berdasarkan analisis laju pertumbuhan spesifik dapat diketahui bahwa nilai tertinggi ditunjukkan oleh perlakuan Guano 0.040 g/L dan Guano $0,080 \mathrm{~g} / \mathrm{L}$ dengan nilai rata-rata $1,88 \%$ per jam, namun tidak berbeda nyata dengan perlakuan Kontrol Positif dengan nilai rata-rata 1,70\% per jam dan Guano 0,100 g/L dengan nilai ratarata $1,77 \%$ per jam. Pada penelitian Kawaroe dkk. (2012), laju pertumbuhan spesifik Spirulina mencapai $1,46 \%$ per jam. Selain kepadatan, perbedan nilai laju pertumbuhan spesifik juga dipengaruhi oleh lamanya waktu pencapaian kepadatan puncak. Perlakuan Kontrol Positif dan Guano 0,100 g/L rata-rata 
menunjukkan kepadatan puncak pada jam ke84. Hal ini diduga karena media perlakuan Kontrol Positif dan Guano 0,100 g/L memiliki nutrisi sedikit lebih tinggi dari media perlakuan lainnya, sehingga membutuhkan waktu lebih untuk pertumbuhan.

Nilai pertumbuhan biomassa pada penelitian ini menunjukkan pengaruh yang tidak signifikan pada nilai biomassa yang diperoleh. Hal ini ditunjukkan pula pada penelitian Prayata dkk. (2013), bahwa kepadatan populasi awal yang berbeda menghasilkan pertumbuhan populasi berbeda pula namun tidak menghasilkan pertumbuhan biomassa yang berbeda, hal ini menunjukkan bahwa dari pemberian perlakuan kepadatan inokulum yang berbeda tidak mempengaruhi pertumbuhan biomassa tetapi hanya pada pertumbuhan populasi saja, diduga karena sel Spirulina sp. menggunakan nutrisi pada lingkungan lebih cenderung untuk bereproduksi yaitu dengan cara pembelahan diri namun tidak dioptimalkan untuk pertumbuhan biomassa. Menurut Chrismadha dkk. (2006), pada media tanpa perlakuan akan tetap tumbuh, dengan adanya kumpulan pigmen fikosianin yang berfungsi sebagai cadangan nitrogen pada sel-sel Spirulina, pada percobaan tanpa perlakuan dapat diinterpretasikan adanya kemampuan Spirulina untuk melakukan fiksasi unsur nitrogen dari udara, mengingat jenis alga ini merupakan bagian dari kelompok cyanobacteria yang banyak jenisnya memiliki kemampuan fiksasi nitrogen bebas. Chrismadha dkk. (2006), juga menyatakan bahwa fenomena menurunnya kandungan protein, klorofil $a$, fikosianin, dan kandungan karbohidrat yang terjadi sejalan dengan degadasi komponen-komponen fungsional sel tersebut memberikan indikasi berkurangnya kemampuan fotosintesis pada kondisi kekurangan unsur hara.

Waktu penggandaan tercepat dicapai pada perlakuan Guano 0,100 g/L dengan nilai ratarata yaitu 36,76 jam. Sebaliknya, perlakuan Kontrol Negatif membutuhkan waktu penggandaan diri paling lama dengan rata-rata 46,57 jam. Hasil waktu penggandan pada perlakuan Guano 0,100 g/L tidak berbeda nyata pada hasil penelitian Utomo dkk. (2005), pada perlakuan kontrol dengan rata-rata yaitu 36,51 jam. Menurut Santosa (2010), bahwa semakin tinggi nilai waktu penggandaan, maka semakin banyak waktu yang dibutuhkan sel untuk menggandakan dirinya, sebaliknya semakin rendah nilai waktu penggandaan, maka semakin sedikit waktu yang dibutuhkan sel untuk menggandakan dirinya. Selain waktu penggandaan diri yang paling lama, perlakuan Kontrol Negatif juga memperlihatkan nilai kepadatan puncak yang rendah. Hal ini diduga karena rendahnya kualitas nutrien yang ada dalam media pada perlakuan ini. Berbeda dengan perlakuan lainnya yang telah ditambahkan pupuk dengan konsentrasi tertentu sehingga dapat menunjang kebutuhan nutrien dalam waktu penggandaan diri Spirulina sp.

\section{Kesimpulan}

Hasil penelitian menujukkan bahwa konsentrasi $0,100 \quad \mathrm{~g} / \mathrm{L} \quad$ menghasilkan pertumbuhan populasi Spirulina sp. tertinggi dan waktu penggandaan diri tercepat. Namun dalam percobaan ini tidak menunjukkan pengaruh yang berbeda nyata terhadap hasil pertumbuhan biomassa

\section{Daftar Pustaka}

Anonim (2016). Kandungan Nutrisi Pupuk Organik Guano. https://organikilo.co/kandungan-nutrisipupuk-organik-guano.htlm $[05,08,2017]$.

Agustini N.W.S. (2010). Aktivitas Antioksidan dan Uji Toksisitas Hayati Pigmen Fikobiliprotein dari Ekstrak Spirulina platensis. Jurnal Biologi, Seminar Nasional IX Pendidikan Biologi FKIP UNS. Vol. 1. Hal. 535-543.

Astiani F., I. Dewiyanti, dan S. Mellisa (2016). Pengaruh Media Kultur yang Berbeda Terhadap Laju Pertumbuhan dan Biomassa Spirullina sp. Jurnal Ilmiah Mahasiswa Kelautan dan Perikanan Unsyiah. Vol. 1. No. 3. Hal. 441-447.

Ayusonia F. (2015). Pertumbuhan Spirulina sp. yang Dikultur dengan Kombinasi Pupuk Urea dan Kotoran Ayam. [Skripsi, unpublished]. Program Studi Budidaya Perairan. Universitas Mataram. Mataram.

Chrismadha T., L.M. Panggabean, dan Y. Mardiati (2006). Pengaruh Konsentrasi Nitrogen dan Fosfor Terhadap Pertumbuhan, Kandungan Protein, Karbohidrat dan Fikosianin pada Kultur Spirulina fusiformis. Jurnal Berita Biologi. Vol. 8. No. 3. Hal. 1-7. 
Ciferri O. (1983). Spirulina the Edible Microorganism. American Society for Microbiology. Vol. 47. No. 4. Hal. 551578.

Fadilla Z. (2010). Pengaruh Konsentrasi Limbah Cair Tahu terhadap Pertumbuhan Mikroalga (Scenedesmus sp.). [Skripsi, unpublished]. Program Studi Biologi. Fakultas Sains dan Teknologi. Universitas Islam Negeri Syarif Hidayatullah Jakarta. Jakarta.

Haryati E. (2010). Pengaruh Pupuk Organik dan Anorganik Terhadap kandungan Logam Berat dalam Tanah dan Jaringan Tanaman Selada. Banda Aceh. Jurnal Floratek. Vol. 5. Hal. 113-123.

Hayati E., T. Mahmud, dan R. Fazil (2012). Pengaruh Jenis Pupuk Organik dan Varietas Terhadap Pertumbuhan dan Hasil Tanaman Cabai. Banda Aceh. Jurnal Floratek. Vol. 7. Hal. 173-181.

Hariyati R. (2008). Pertumbuhan dan Biomassa Spirullina sp. dalam Skala Laboratoris. Jurnal BIOMA. Vol. 10. No.1. Hal. 19-22.

Hermansyah A. (2015). Penambahan Garam dalam Budidaya Spirulina sp. di Air Tawar. [Skripsi, unpublished]. Program Studi Budidaya Perairan. Universitas Mataram. Mataram.

Hidayah H.A. (2005). Pertumbuhan dan Pasca Panen Mikroalga Hasil Kultur Skala Semi Massal.

http://bio.unsoed.ac.id/sites/default/files/P ertumbuhan dan Pasca Panen Mikroalga Hasil Kultur Skala Semi Massal-.pdf. [27,08,2017].

Kawaroe M., T. Prartono, A. Rachmat, D.W. Sari, dan D. Augustine (2012). Laju
Pertumbuhan Spesifik dan Kandungan Asam Lemak pada Mikroalga Spirulina platensis, Isochrysis sp. dan Porphyridium cruentum. Jurnal Ilmu Kelautan. Vol. 17. No. 3. Hal. 125-131.

Prayata L.H.D., S. Waspodo, dan A.A. Damayanti (2013). Pengaruh Kepadatan Inokulum Terhadap Pertumbuhan Populasi dan Biomassa Spirulina sp. . Jurnal Perikanan Unram. Vol. 3. No. 2. Hal. 48-55.

Santosa A. (2010). Produksi Spirulina sp. yang Dikultur dengan Perlakuan Manipulasi Fotoperiod. [Skripsi, unpublished]. Program Studi Teknologi dan Manajemen Perikanan Budidaya. Fakultas Perikanan dan Ilmu Kelautan, Institut Pertanian Bogor. Bogor.

Sari F.Y.A., I Made Suryajaya, dan Hadiyanto (2012). Kultivasi Mikroalga Spirullina platensis dalam Media Pome dan Komposisi Jumlah Nutrien. Jurnal Teknologi Kimia dan Industri. Fakultas Diponerogo. Vol. 1 No. 1. Hal. 487-494.

Suantika G., dan D. Hendrawandi (2009). Efektivitas Teknik Kultur Menggunakan Sistem Kultur Statis, Semi-kontinyu, dan Kontinyu terhadap Produktivitas dan Kualitas Kultur Spirulina sp. Jurnal Matematika dan Saints. Vol. 14. Hal. 4149.

Utomo N.B.P., Winarti, dan A. Erlina (2005). Pertumbuhan Spirullina platensis yang Dikultur dengan Pupuk Inorganik (Urea, TSP dan ZA) dan Kotoran Ayam. Jurnal Akuakultur Indonesia. Vol. 4. No. 1. Hal. 41-48. 